\title{
Landscaping an Ecuadorian Neighborhood in Queens, NY*
}

\author{
PATRICIA GUBITOSI** \\ CHRISTIAN PUMA*** \\ DANIELA NARVÁEZ****
}

Recepción: 10 de marzo de 2020

Aprobación: 7 de junio de 2020

How to cite this article: Gubitosi, P., Puma, C. \& Narváez, D. (2020). Landscaping an Ecuadorian Neighborhood in Queens, NY. Cuadernos de Lingüística Hispánica, (36), 211-234.

* Research article.

** Associate Professor of Hispanic Linguistics at the University of Massachusetts Amherst where she teaches graduate and undergraduate courses in sociolinguistics and Spanish dialectology. She is the coeditor of El español en la red (Iberoamericana, 2018), and author of La Expresion de la Pasividad en el Sudoeste de los Estados Unidos y Mexico (1855-1950) (Peter Lang, 2013), in addition to have published in journals such as Language Studies and Camino Real. E-mail: pgubitosi@umass.edu (Dhttps://orcid.org/0000-0003-1117-8886

*** Doctoral student in the program of Spanish and Portuguese in the Department of Languages, Literatures and Cultures of the University of Massachusetts Amherst. His research interests include sociolinguistic of the Ecuadorean diaspora, dialects of Ecuadorean Spanish and the linguistic landscape of Latino communities. E-mail: cpuma@umass.edu @https://orcid. org/0000-0002-0063-9416

***** Doctoral student of the graduate program in Spanish and Portuguese at the University of Massachusetts Amherst. Her research interests include linguistic identity of minority groups, dialectology of Ecuadorean Spanish and the linguistic landscape as a tool for studying minority groups. E-mail: mnarvaezburb@umass.edu (ib https://orcid.org/0000-0003-0289-0169 


\begin{abstract}
Diaspora studies on migration communities have shown how these transnational groups appropriate the new space in the receptive country through a process of deterritorialization and reterritorialization. These processes involve a reinterpretation and reconceptualization of the linguistic relationship between the language of the diaspora group and those spoken in the new home. One of the most visible places where this contextual relation must be negotiated is in the public sphere, where language, culture and identity are inevitably interwoven (Blackwood, Lanza \& Woldemariam, 2016). Using a multimodal approach and using both qualitative and quantitative methodologies, this article analyzes how an Ecuadorian-American community in Queens transformed the linguistic landscape of their surroundings to make it similar to what this community had in their home country.
\end{abstract}

Keywords: Linguistic landscaping, Ecuadorian diaspora, minority community, Spanish in the U.S.

\title{
Diseño lingüístico de un barrio ecuatoriano en Queens, Nueva York
}

\section{Resumen}

Los estudios de diáspora sobre las comunidades migrantes muestran que estos grupos transnacionales se apropian del nuevo espacio en el país receptor a través de un proceso de deterritorialización y reterritorialización. Estos procesos involucran una reinterpretación y una nueva conceptualización de la relación lingüística entre la lengua del grupo diaspórico y aquella del país de origen. Uno de los lugares más visibles donde esta relación debe negociarse es en la esfera pública, donde la lengua, la cultura y la identidad están estrechamente interrelacionadas (Blackwood, Lanza \& Woldemariam, 2016). A través de una perspectiva multimodal y tomando en consideración metodologías cualitativas y cuantitativas, este artículo analiza cómo la comunidad ecuatorianaestadounidense que vive en Queens, ciudad de Nueva York, transformó el paisaje lingüístico de su entorno para convertirlo en uno semejante al que tenían en su país de origen. 
Palabras clave: paisaje lingüístico, diáspora ecuatoriana, comunidad minoritaria, español en los Estados Unidos.

\section{Le paysage linguistique d'un quartier équatorien dans le Queens, NY}

\section{Résumé}

Les études de la diaspora sur les communautés de migrants montrent que ces groupes transnationaux s'approprient le nouvel espace dans le pays d'accueil à travers un processus de déterritorialisation et de reterritorialisation. Ces processus engagent une réinterprétation et une nouvelle conceptualisation de la relation linguistique entre la langue du groupe diasporique et celle du pays d'origine. L'un des scénarios le plus visible où ce rapport doit être négocié est celui de la vie publique où la langue, la culture et l'identité sont étroitement liées (Blackwood et al.2016). Par le biais d'une perspective multimodale et tout en tenant compte des méthodologies qualitatives et quantitatives, cet article analyse la manière dont la communauté américano-équatorienne vivant dans le Queens, à New York, a transformé l'horizon linguistique de leur environnement pour le transformer en un paysage similaire à celui qu'ils avaient dans leur pays d'origine.

Mots clés: paysage linguistique, diaspora équatorienne, communauté minoritaire, espagnol aux États-Unis.

\section{A paisagem lingüística de um bairro equatoriano em Queens, NY}

\section{Resumo}

Estudos da diáspora sobre comunidades migrantes mostram que esses grupos transnacionais se apropriam do novo espaço no país receptor através de um processo de desterritorialização e reterritorialização. Esses processos envolvem uma reinterpretação e uma nova conceituação da relação linguística entre a língua do grupo diaspórico e a do país de origem. Um dos lugares mais visíveis onde essa relação deve ser negociada é na esfera pública, onde língua, cultura e identidade estão intimamente relacionadas (Blackwood et al. 2016). Por uma perspectiva multimodal e levando em conta metodologias qualitativas e quantitativas, este artigo analisa como a comunidade equatoriano-americana que vive em Queens, Nova York, transformou o cenário linguístico de seu ambiente para transformá-lo em um semelhante ao que tinham em seu país de origem. 
Palavras-chave: paisagem linguística, diáspora equatoriana, comunidade minoritária, espanhol nos Estados Unidos.

\section{Introduction}

Diaspora studies on migration communities have shown that transnational groups take possession of the new space in the host country with a process of re-territorialization (Rosa, 2015; Gubitosi, 2019); this involves both a reinterpretation and reconceptualization of the linguistic relationship between the ethnic language and the language(s) spoken in the new home. The term diaspora, indeed, refers to practices of dispersion and displacement where people become established in a new country and build a new imagined community (Anderson, 1991), without cartographic and geographical borders, as "a cultural construct or the product of a cultural renaissance" (Laughlin, 2001, p. 230). This process that creates a new home far from their original home reinforces the symbolic bonds with their native land, to which diasporic groups pledge their allegiance.

One of the most visible places where this contextual relation must be negotiated -in a peaceful or violent manner- is in the public sphere, where language, culture and identity are inevitably interwoven (Blackwood et al., 2016). In this way, linguistic landscape (LL) becomes "the symbolic construction of the public space" (Ben-Rafael, Shohamy, Amara \& Trumper-Hecht, 2006; Ben-Rafael, 2009; Shohami, 2015; among others) where people fight their battles to either survive or disappear as a group. This highlights the role that LL plays in representing the sociocultural, ideologized and multidiverse world in which we live. For example, Pütz and Mundt (2019) point out:

In multilingual and multicultural communities, people and passers-by are surrounded by a multitude of languages and language contact phenomena (such as code switching, code mixing and borrowing) as well as visual imagery which appear in public places. (p. 2)

In addition to this complex reality for the newcomers, we need to take into account that nowadays migrants are not always looking to return to their country of origin. Instead, they may plan on staying and helping other compatriots to also establish themselves in the same place, as "new migrants typically settle in older immigrant neighborhoods, which thus develop into a layered immigrant space (Bloommaert, 2010, p. 7)”. The community offers newcomers spaces to rent, in areas where new segments of the labor market can be developed. 
In order to account for this multilayered space, Vertovec (2007, p. 1024) has proposed the term superdiversity to describe the characteristics of this new global immigration:

Such a condition is distinguished by a dynamic interplay of variables among an increased number of new, small and scattered, multiple-origins, transnationally connected, socio-economically differentiated and legally stratified immigrants who have arrived over the last decade. (p. 1024)

With superdiversity, a diaspora community is not a homogeneous group of people who share the same country of origin, but instead it is a group of people who frequently have different backgrounds, culture and traditions. As Canagarajah and Silberstein (2012) point out, diaspora groups express difference, not similarity, and the affinity and solidarity among people with the same heritage must be achieved situationally through language.

An iconic multilingual, multidiverse and multicultural city where this statement can be verified is New York City, New York (NYC), in the northeastern coast of the United States. NYC has a remarkable ethnic and racial diversity as a product of its rich immigrant history. This has resulted in a creative multiculturalism which allows the "interactions between the second generation, native minorities, and native whites" (Foner 2007, p. 1015). Recent data from the Census Bureau (2018) indicate that $37 \%$ of the total population of NYC was born in a foreign country and, moreover, $49 \%$ of the total population of the city speaks a language other than English at home.

Latinos /Hispanics are one of the most prominent ethnic groups in NYC, as they account for $29 \%$ of the total population. Among them, Ecuadorians are the fourth largest group with 198,854 inhabitants, after Puerto Ricans $(718,473)$, Dominicans $(707,615)$ and Mexicans $(343,275)$. Nevertheless, when looking at specific data of Queens County, Ecuadorians are the second largest group of Latin American immigrants (114,932 inhabitants $\left.{ }^{1}\right)$, immediately after Puerto Ricans $(115,672)$ and followed by Dominicans $(103,241)$.

This paper analyzes the linguistic landscape of the Ecuadorian community in Queens, New York, where Ecuadorians, even though they are one of the biggest ethnic communities in the city, must share the public space with other Hispanic/ Latino groups. Our goal is twofold: 1) to see if there is any difference between Ecuadorian signages

1 As it happens with other Latino immigrant groups, this number must be carefully considered since several Ecuadorians could have decided not to respond the Census and be kept under radar. 
versus those produced by people from different Latin American origins, and 2) to analyze how Ecuadorians in the diaspora build their transnational identities using the linguistic landscape as a resource to show their allegiances to their home and host countries. This study will further the discussion on using linguistic landscape as a tool for expanding our sociolinguistic knowledge on diaspora and multicultural communities.

\section{Linguistic Landscape in Multicultural Settings}

According to Aronin and Singleton (2012), multilingualism needs three main components: language users, the languages themselves and an environment where they come together. This environment is where signals in the LL often occur. Moreover, it is through the lens of LL that sociolinguists uncover the diverse reality of "language used in signage and in speakers' public displays, performances and interaction" (Stroud \& Mpendukana 2009, p. 364).

This last statement on LL expands on earlier descriptions of LL as the "language of public road signs, advertising billboards, street names, place names, commercial shop signs, and public signs on government buildings" (Landry \& Bourhis, 1997), or "any piece of written text within a definable frame" (Backhaus 2007, p. 56). Stroud and Mpendukana's (2009) definition of LL, highlights the multifaceted and dynamic reality of language display in the public arena. Furthermore, $L L$ is not represented as a motionless set of signs placed on public buildings or the street, but as a dynamic activity in which people and LLs interact and influence each other to build the landscape of their communities (Bernardo-Hinesley \& Gubitosi, s.f.). For example, when a business owner of a sporting goods store displays t-shirts of a specific soccer team, it is because he is targeting customers from a specific city of a particular Latin American country. Nevertheless, if a different soccer team becomes more popular and people start wanting those $\mathrm{t}$-shirts, the business owner would probably re-arrange the visual display of his store in order to satisfy the increasing demand. The cumulative posters and signages that are frequently displayed in the public space become a collective assemblage of meaning that takes into account "the way things are brought together and function in new ways" (Pennycook, 2016, p. 80). If the assemblage were arranged in a different fashion, the meaning described by it would then be different. The concept of assemblages acknowledges how diverse trajectories of people, semiotic resources and objects come together at particular time and space (Pennycook, 2016).

In the last few decades, multilingualism has increased in visibility because of globalization and transnational mobility. As more people resettle themselves in different countries, more languages come into contact with each other, not only in daily 
personal conversations, but also in the space where this contact transpires. In other words, "everyday mobility produces contact situations between people from different backgrounds in regard to their migration status, education, social class, employment, etc." (Salzmann, 2013, p. 22).

As migrants strive to recreate their old communities in the new country, public spaces become crucial for people to produce meaning that creates inclusiveness in the new place. According to Nayak (2010, p. 2389), people's 'sense of place' is related with "ideas of nation, region, home, or locality as geographically located and emotionally experienced". Thus, when migrants go through the process of reconceptualization, which involves territorializing the new home, they become intensely engaged with different culture(s) and language(s) in order to make the new space "a non-neutral (even agentive) zone, where specific identities, actions and meanings can be generated" (Bloammert, 2013, p. 21).

Globalization and the highly diverse scenario that emerges from it not only have a significant impact on how we live, "but also on how our identities and communities are formed, our patterns of belonging" (Carson \& King, 2016, p. 3). In this regard, LL plays an important role "in constructing an imaginary community built on the myth of the old homeland" (Woldemariam \& Lanza, 2015, p. 173). Signage not only communicates informative content, but it also communicates symbolic meaning. For instance, shop signs can display the services provided, yet they can simultaneously reveal the identity of the owner, whether real or imagined (Bogatto \& Hélot, 2010 Gorter, 2006; Malinowski, 2009; Woldemariam \& Lanza, 2015).

\section{Ecuadorians in the Linguistic Landscape of Queens, NY}

Ecuadorian migrants started their settlements in the US at the end of the 1960s due to the worsening economic conditions in the rural Ecuadorian towns where they lived. The areas where they came from show evidence of their low educational preparation (Gratton, 2005, 2007). Gratton (2007 p. 584) states that, " 40 per cent of Ecuadorians in the New York area had not achieved a high school education, and only 10 percent had college degrees." Most Ecuadorian males worked in the food service industry, the majority as waiters, cooks and helpers; however, as Gratton (2007) also points out, more than 10 percent had managerial, supervisory or professional occupations. This group was able to thrive despite their lack of academic preparation. 
The second wave of immigration from Ecuador to Queens, NY, occurred in the 1990s and was demographically different than the previous one. According to Gratton (2007):

a severe economic crisis in an already poor nation transformed emigration from this conventional pattern to a novel one [and] the new migrants differed in key respects from those in the traditional streams, indeed from much of what we know from the history of immigration. They were urban rather than rural in background. Relatively well educated, with good occupational skills, they left from all regions, rather than those with a deep tradition of migration. (p. 581)

Finally, the new and last arriving group of immigrants has continuously settled in Queens, NY since the beginning of the 21st century, as the main chosen place of resettlement. They established their presence all along Roosevelt Avenue, where Ecuadorian businesses remain prevalent. Ecuadorians have maintained strong ties with their native land managing to recreate restaurants, tourist agencies, supermarkets, driving schools, money exchange offices, etc., as their own imagined community in the global city of New York. Nevertheless, while reproducing this new sense of Ecuadorian place in the diaspora, Ecuadorians also need to make alliances with other cultural groups with whom they have to share the same space. As Stroud (2016) points out, LL "is one powerful means of affective rendering" that creates inclusiveness, favors conviviality and resists marginalization, while at the same time, enhances people's sense of belonging, alleviating the anxiety of being home far away from home.

We agree with Woldemariam and Lanza (2015) in the sense that, for people living in the diaspora, LL serves as a strategy not only to maintain their transnational identity but also to construct a unique identity in the recipient society.

This article, therefore, analyzes how Ecuadorian-American community in Queens transformed the LL of their surroundings to make them similar to what they had in their home country, and how they differentiate themselves from other Latino groups in the area.

\section{Methodology}

Many LL studies draw on well-known existing research methods and techniques from sociolinguistics, applied linguistics, among other disciplines, which were all taken into account to determine the methodology for this study. 
The first consideration was to set the geographic perimeter of study. The questions that raised were how to choose it? and what is the most relevant focal geographical area? (Hult, 2014). Huebner (2006, p. 32) hints at the importance of a neighborhood as a survey area; in his study in Bangkok, he observed "separate and identifiable neighborhoods each with its own linguistic culture". As previously mentioned, this is also the case in NYC. Latin American diaspora has settled in Queens since the 1960s, and by 2015, 52\% of the total of the Latino population in New York lived in Queens (Bergad, 2016). Moreover, according to Cenoz and Gorter (2006), another frequent practice in LL studies is to focus on one or more commercial streets. Based on these previous studies, we identified a Latino neighborhood and one of its most relevant and well-known commercial streets as our area of study. After conducting several interviews with people of Ecuadorian origin in Queens, we chose Roosevelt Avenue, where many Latin America diaspora communities have established their businesses. This avenue begins at 48th Street and Queens Boulevard and ends at 156th Street and Northern Boulevard. Roosevelt Avenue also goes through Woodside, Jackson Heights, Elmhurst, Corona, Flushing Meadows-Corona Park and Flushing (Figure 1).

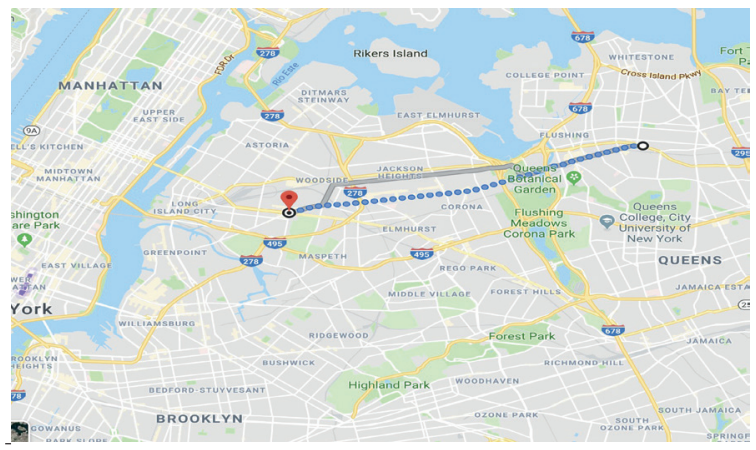

Figure 1. Map: Roosevelt Avenue, Queens, NY.

Source: Google Maps.

In order to determine the streets for our particular group of study, we considered information extracted from our interviews, Google Maps, and previous fieldwork. For this reason, the corpus of this study includes a complete inventory of the LL of all signs and posters found on Roosevelt Avenue between 80th Street and 111th Street (Figure 2). 


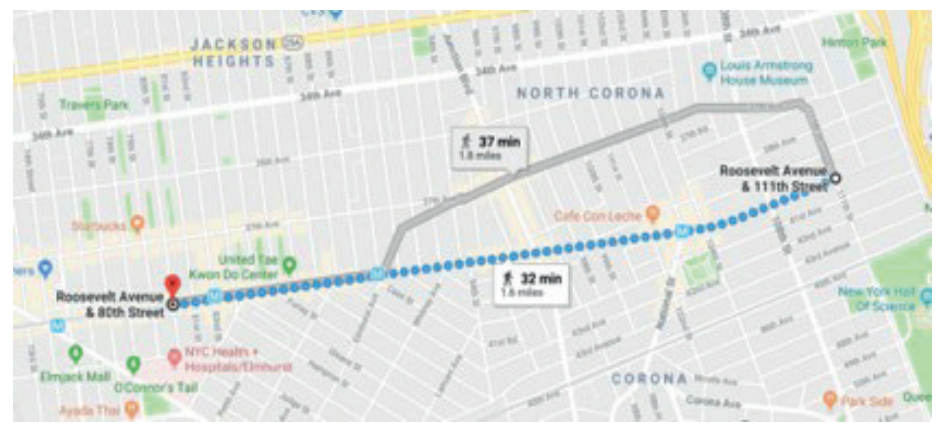

Figure 2. Map: Area of study. Source: Google Maps.

-Our approach involved taking digital pictures of all signage, or fixed texts, that we saw on the street, following the methodology proposed by Cenoz and Gorter (2006). Moving texts, such as signs on buses, trucks and taxis, were not considered in this study as we were interested in comparing Ecuadorian signage with that of other Latino groups, specifically focusing on the signage of business and shop stores.

We analyzed a total of 847 photos from which we classified all the texts. In the end, we distinguished 1085 units, which were divided into signs and posters. The signs were the texts that specifically belonged to a particular store, while the posters were the ones found along the avenue on walls and lampposts (Table 1).

Table 1. Total of signals of analysis

\begin{tabular}{|c|c|c|c|c|c|}
\hline & $\begin{array}{c}\text { Number of } \\
\text { pictures }\end{array}$ & $\begin{array}{c}\text { Number of } \\
\text { business }\end{array}$ & $\begin{array}{c}\text { Number of } \\
\text { signs }\end{array}$ & $\begin{array}{c}\text { Number of } \\
\text { Posters }\end{array}$ & $\begin{array}{c}\text { Total of } \\
\text { Units }\end{array}$ \\
\hline Total & 847 & 685 & 1004 & 81 & $\mathbf{1 0 8 5}$ \\
\hline
\end{tabular}

Establishing the unit of analysis in the studies of LL has been one of the main issues for researchers. On one hand, some consider 'the larger whole of the establishment as the unit of analysis,' which means taking into consideration the 'façade of a shop or house and not the individual house' (Cenoz \& Gorter, 2006; Vanderbrouck, 2015). On the other hand, the most common definition for 'unit of analysis', according to Backhaus (2007, p. 66), is 'any piece of text within a spatially definable frame'. In the following paragraphs we explain how we identified our unit of analysis depending on the kind of text, signs or posters found along Roosevelt Avenue.

First, each of the signs that were found in stores and other businesses were considered as a unit of analysis. For instance, when a restaurant had its name on the front but also three advertising signs on the windows, we considered them as four different signs or units of analysis (Figure 3). 


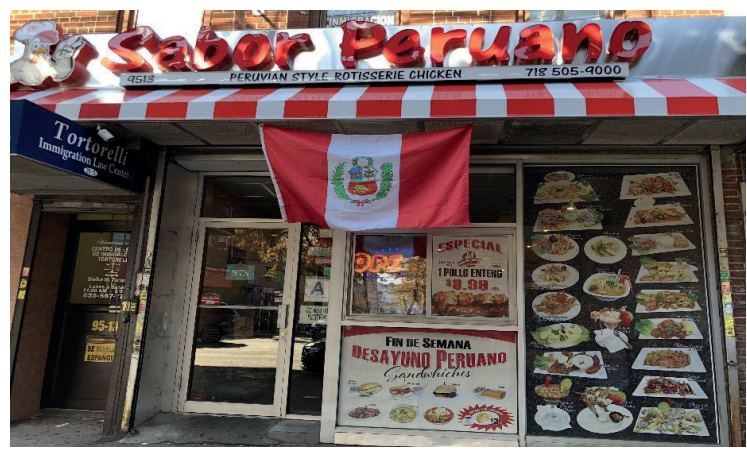

Figure 3. Peruvian Restaurant

When considering the unit of analysis for posters, in the majority of cases, many of the same posters were found as advertisements on the same wall or lamppost. Taking into consideration that our unit of analysis is the signage, some of the problems that past researchers have encountered in quantifying all of the occurrences was because of this type of repetition of the same signage in the same places (Gorter, 2018). When this was the case, we decided to count them as one unit of analysis because one is able to see the same information at once in an assemblage. For example, in Figure 4, we found eight posters, from which five of them advertised the same concert, and the other three advertising a different one; thus, we considered this as two units of analysis, assuming that meaning is constructed in this case by repetition and iteration.

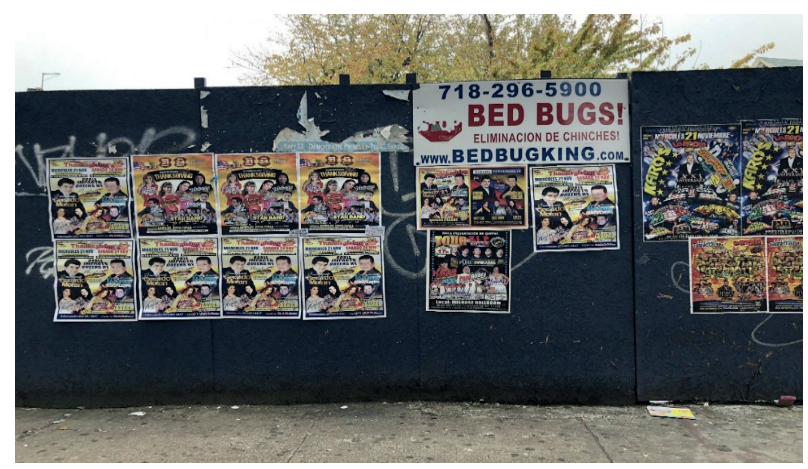

Figure 4. Concert posters

In this sense, we recognize that LL must be analyzed with a broader, multimodal perspective, as we need to take into consideration the relationship among the different codes (letters, colors and other semiotic symbols). We agree with Lytra (2012) who states that 
adopting a multimodal perspective implies a theoretical and analytical shift for studies on multilingualism from focusing exclusively on language as the primary site for meaning making to recognizing the role that other modes (visual, aural, oral, kinaesthetic artifact-related) and media play in the communication landscape. (p. 533)

LL conveys "meaning in terms of identity marketing, testifying to the special ties binding a priori actors and given categories of clients" (Ben-Rafael, Shohamy \& Barni, 2010, p. xix). Accordingly, we assume that if words can be combined in sentences to make meaning in texts, LL signs do not make sense in isolation but only its membership of a system (Machin, 2007). In the next section we discuss our results.

\section{Discussion and Results}

The results of this study show which languages are displayed in all signage from 80th Street to 111th Street along Roosevelt Avenue and the characteristics of bilingual signs pertaining to language use among the Latino community. Our analysis includes a total of 685 shops which belonged to different Latin American communities (Table 2), where the majority pertains to different communities other than Latinos such as Chinese, Korean or Anglo-American groups.

Table 2. Total of shops by country

\begin{tabular}{|c|c|c|c|c|c|c|}
\hline Shops & Ecuador & Colombia & Mexico & Latin America & Others & Total \\
\hline $\mathbf{n}$ & 65 & 22 & 50 & 45 & 503 & $\mathbf{6 8 5}$ \\
\hline
\end{tabular}

We then identified the most prominent communities, which were Ecuador, Colombia, and Mexico, as they stood out from any other Latin American diasporas because of their numbers. Therefore, we decided to code our data using these three countries, other Latin American ones and other non-Latino ones. We grouped all the shops from Latin America in one category because we could either identify the country, but it was not quantitatively significant (e.g. Peru, Dominican Republic, El Salvador, Nicaragua), or we knew it was a Latin American business, but we could not identify the specific country to which it belonged (they either used Spanish language or included the term 'Latin American store'). Among businesses that did not have any distinctive signage, there were big corporations (e.g. Bank of America, Taco Bell, McDonald's, etc.) or other businesses that did not specify their country in any way. In such cases, we grouped them as others. Furthermore, our data match previous ethnographic studies in the area, such as Bergad (2016), in which he states that Colombians, Mexicans, and Ecuadorians are some of the most prominent Latino communities in New York. Moreover, according to Bergad's study 
(2016), of the total population of these nationalities in the city, $56 \%$ of Ecuadorians, $70 \%$ of Colombians and 31\% of Mexicans live in Queens.

When taking a closer look at the data, we also realized that each of these nationalities also stands out by the type of businesses they have established in Queens. Ecuadorians have a wider variety of shops compared to any other communities; for instance, they have a driving school, bank agency, dentist office, barber shops, etc., which show how this community has re-territorialized this space and made it into one similar to their home community. On the other hand, if we take the data from the Mexican and Colombian communities, we see that they stand out for industries that have been widely acknowledged. For instance, the Colombian community has ten shops that are related to Colombian clothing (jeans, shapewear, etc.), and, since Mexican food is known worldwide and is very popular in the United States, Mexican restaurants are the most prominent (31) in their respective area.

Then, from all the businesses, we classified a total of 1004 signs and 81 posters or sets of posters. Our codifications for each sign and poster were divided into subcategories. The first group was based on the country of origin where each sign or poster was from. To achieve this, we paid attention to different semiotic symbols: flags, code of arms, colors, and regionalisms, among others (Table 3). Once again, Mexican, Colombian and Ecuadorian signages were the most prominent. However, as previously mentioned, our main objective was to identify the different language choices among each community. Therefore, based on Ben-Rafael, Shohamy, Amara and Trumper-Hecht (2001), we included the number of languages on the signage, monolingual (Spanish or English) and bilingual (Spanish-English or English-Spanish), in our classifications. In the case of bilingual signage, we took into consideration the order of the languages and the size of the fonts to decide which language was the most relevant or prevalent. Thus, if a sign was classified as Spanish-English bilingual, it was because either the amount of Spanish language surpassed the English, or because Spanish had more saliency in terms of bigger letters, positioning on the sign, etc.

Table 3. Total of signs and posters by country

\begin{tabular}{|c|c|c|c|c|c|}
\hline & Ecuador & Colombia & Mexico & $\begin{array}{c}\text { Latin } \\
\text { America }\end{array}$ & Others \\
\hline Number of signs & 168 & 67 & 105 & 59 & 605 \\
\hline Number of posters & 43 & 0 & 21 & 7 & 10 \\
\hline
\end{tabular}


We also classified each sign and poster by the language used in each country and added a multimodal perspective analysis of the whole material which not only included linguistic signs but also relevant semiotic information.

In Table 4 we can see that the majority (69.6\%) of signs that are only in Spanish are the Ecuadorian signs, followed by the Mexican (62.9\%) and Colombian (47.8\%) signs. However, only $13.4 \%$ of signs from Colombia, $7.6 \%$ from Mexico and $5.4 \%$ from Ecuador preferred to use monolingual English signs. It is also important to notice that the percentage of Spanish language used by Ecuadorians in signs and posters is higher than what was used by other Latin American groups.

In the case of bilingual signs, the majority of the Colombian ones (34.3\%) showed a preference of Spanish-English, followed by Mexico (21.9\%) and Ecuador (21.4\%); on the contrary, English-Spanish bilingual signs showed lower percentages in all communities (Mexico 7.6\%; Colombia 4.5\% and Ecuador 3.6\%).

Table 4. Language preference in signs

\begin{tabular}{|c|c|c|c|c|c|c|c|c|c|c|}
\hline \multirow{2}{*}{\multicolumn{3}{|c|}{$\begin{array}{c}\text { Number of signs } \\
\text { Spanish }\end{array}$}} & \multicolumn{8}{|c|}{ Language preferences } \\
\hline & & & \multicolumn{2}{|c|}{ English } & \multicolumn{2}{|c|}{$\begin{array}{c}\text { Spanish - } \\
\text { English }\end{array}$} & \multicolumn{2}{|c|}{$\begin{array}{l}\text { English - } \\
\text { Spanish }\end{array}$} & \multirow[b]{2}{*}{$\mathrm{N}$} & \multirow[b]{2}{*}{$\%$} \\
\hline & $\mathrm{n}$ & $\%$ & $\mathrm{n}$ & $\%$ & $\mathrm{~N}$ & $\%$ & $\mathrm{n}$ & $\%$ & & \\
\hline Ecuador & 168 & $16.7 \%$ & 117 & $69.6 \%$ & 9 & $5.4 \%$ & 36 & $21.4 \%$ & 6 & $3.6 \%$ \\
\hline Colombia & 67 & $6.7 \%$ & 32 & $47.8 \%$ & 9 & $13.4 \%$ & 23 & $34.3 \%$ & 3 & $4.5 \%$ \\
\hline México & 105 & $10.5 \%$ & 66 & $62.9 \%$ & 8 & $7.6 \%$ & 23 & $21.9 \%$ & 8 & $7.6 \%$ \\
\hline Latin American & 59 & $5.9 \%$ & 31 & $52.5 \%$ & 7 & $11.9 \%$ & 19 & $32.2 \%$ & 2 & $3.4 \%$ \\
\hline others & 605 & $60.2 \%$ & 123 & $20.3 \%$ & 216 & $35.7 \%$ & 104 & $17.2 \%$ & 162 & $26.8 \%$ \\
\hline
\end{tabular}

A similar situation occurred when we analyzed the language preference of the posters found along these streets (Table 5). It is interesting to notice that most of the 
posters and assemblages of posters were identified as Ecuadorians, whereas we could not find any from Colombia. This also demonstrates the big presence of the Ecuadorian community in the neighborhood. Moreover, Ecuadorians preferred to use only Spanish (81.4\%), followed by other Latin American diaspora (71.4\%), Mexicans (61.9\%) and other communities (50\%).

The second choice for these communities was to use bilingual posters (SpanishEnglish). While the average of Spanish use on the signage was very similar, we must keep in mind that the absolute number of Ecuadorian posters doubles the Mexican ones and is six times greater than the posters from other Latin American groups.

Table 5. Language preference in posters

\begin{tabular}{|c|c|c|c|c|c|c|c|c|c|c|}
\hline \multirow{2}{*}{\multicolumn{3}{|c|}{$\begin{array}{c}\text { Number of posters } \\
\text { Spanish }\end{array}$}} & \multicolumn{8}{|c|}{ Language Preference } \\
\hline & & & \multicolumn{2}{|c|}{ English } & \multicolumn{2}{|c|}{$\begin{array}{l}\text { Spanish - } \\
\text { English }\end{array}$} & \multicolumn{2}{|c|}{$\begin{array}{l}\text { English } \\
\text { Spanish }\end{array}$} & \multirow[b]{2}{*}{$\mathbf{N}$} & \multirow[b]{2}{*}{$\%$} \\
\hline & $\mathbf{n}$ & $\%$ & $\mathbf{n}$ & $\%$ & $\mathbf{n}$ & $\%$ & $\mathbf{n}$ & $\%$ & & \\
\hline Ecuador & 43 & $53.1 \%$ & 35 & $81.4 \%$ & 0 & $0 \%$ & 8 & $18.6 \%$ & 0 & $0 \%$ \\
\hline Colombia & 0 & $0 \%$ & 0 & $0 \%$ & 0 & $0 \%$ & 0 & $0 \%$ & 0 & $0 \%$ \\
\hline México & 21 & $25.9 \%$ & 13 & $61.9 \%$ & 1 & $4.8 \%$ & 4 & $19.0 \%$ & 3 & $14.3 \%$ \\
\hline $\begin{array}{c}\text { Latin } \\
\text { America }\end{array}$ & 7 & $8.6 \%$ & 5 & $71.4 \%$ & 0 & $0 \%$ & 2 & $28.6 \%$ & 0 & $0 \%$ \\
\hline Others & 10 & $12.4 \%$ & 5 & $50 \%$ & 2 & $20 \%$ & 3 & $30 \%$ & 0 & $0 \%$ \\
\hline
\end{tabular}

Therefore, we can conclude that the language preference for signs and posters in the area under study is Spanish, which makes the presence of Latino communities relevant to build the LL of this area.

When it comes to non-Latino communities, despite English being the most relevant language, the Latin American diaspora pushes them to add Spanish signs into their businesses. As can be observed in Figure 5, although the owners of this shop do not have a Latin American background, they have chosen to include signs in Spanish to appeal to the Hispanic community. We further noticed that the signs were not written by a native speaker of Spanish but were literally translated from English. 


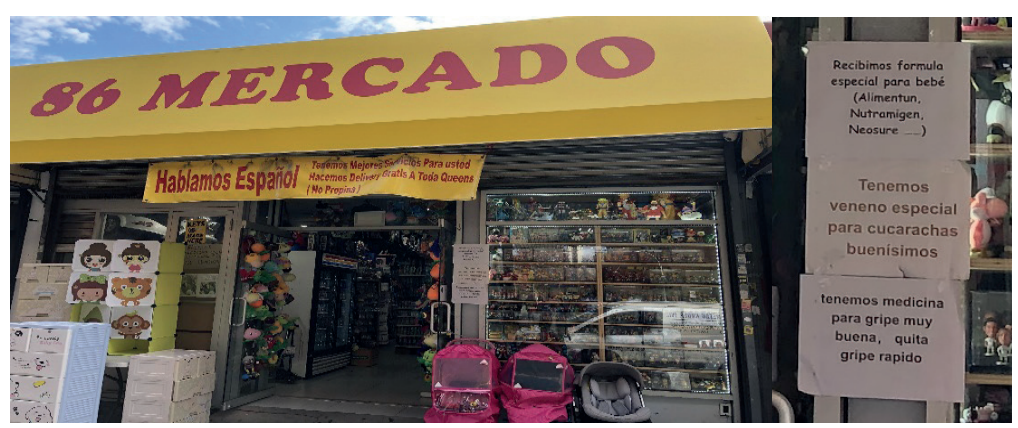

Figure 5. Non-Latino shop

In addition to the use of semiotic elements and Spanish language to build the LL of their surroundings, Ecuadorians also draw upon regionalisms and their Spanish language variety to attract the Ecuadorian community and reinforce the idea of territorializing the neighborhood as their new home. On the contrary, Mexicans already have a more extended presence in the United States and, therefore, use symbols such as the 'sombrero', a chili pepper or an avocado to identify themselves (Figure 6).

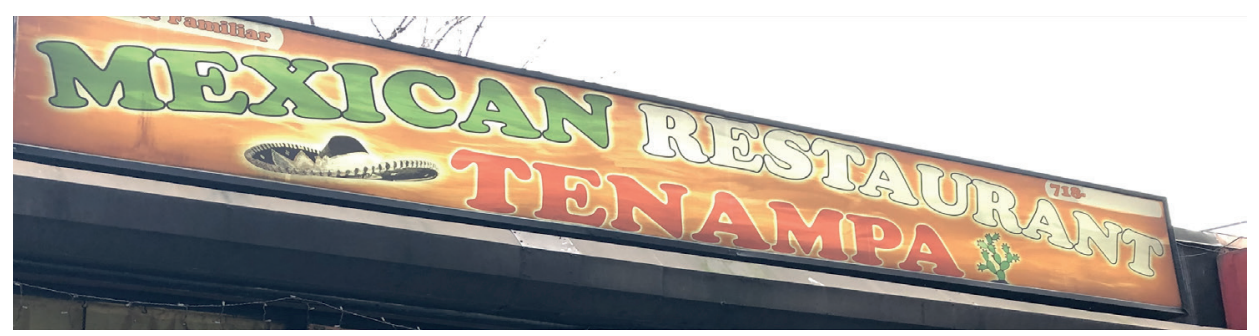

Figure 6. Mexican restaurant

Ecuadorians not only stand out with the use of Spanish, but also combine it with other symbols and the use of colloquial language that appeals uniquely to Ecuadorian identity such as using appellatives, diminutives/superlatives or regionalisms in the names of their businesses.

In Figure 7, we can see the use of the appellative "Luz de América", which makes reference to Quito. In Figure 8, we see another example "La Perla del Pacífico", which makes reference to Guayaquil. Thus, these places can mainly be identified as Ecuadorians, by Ecuadorians. 


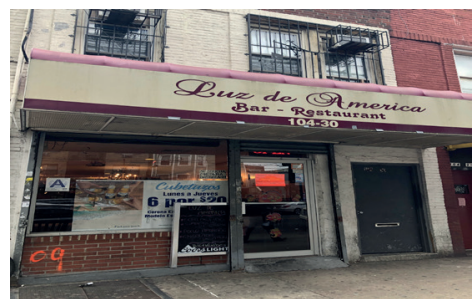

Figure 7. Ecuadorian restaurant

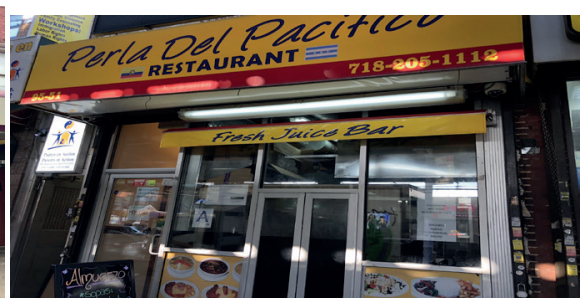

Figure 8. Ecuadorian restaurant

They also utilize specific features of their linguistic variety, such as the use of diminutives as a distinction marker, since the suffix -ito is extremely frequent in Andean Ecuadorian Spanish (Lipsky, 2003). We can see this in figures 9 and 10, in which those businesses use the names of two provinces in Ecuador, Azogues and Ambato, in the diminutive form (Azogueñita and Ambateñita).

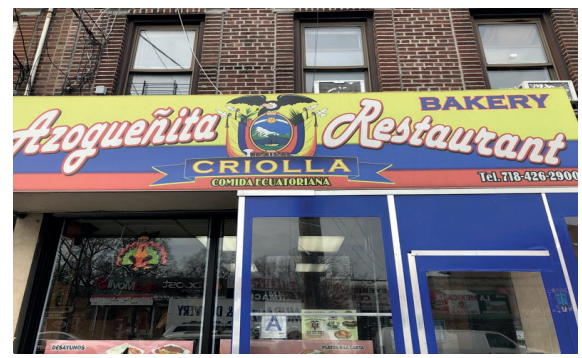

Figure 9. Ecuadorian restaurant

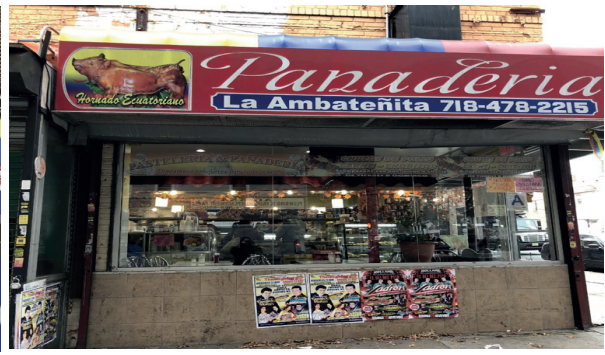

Figure 10. Ecuadorian restaurant

Finally, we also found that Ecuadorians use some regionalisms, which are expressions or words used by speakers in a particular geographical area, which in this case is Ecuador. One example is the restaurant called "Vasija de barro"; this term means "clay pot" and is known and used in many places in South America (Figure 11). However, this phrase references a very popular song written by Ecuadorian poet Jorge Carrera. In writing these lyrics, he was inspired by the Ecuadorian painter Oswaldo Guayasamin when he told him that the Incas buried their relatives inside the pot along with food:

Yo quiero que a mi me entierren

como a mis antepasados

en el vientre oscuro y fresco

de una vasija de barro. 
Another regionalism that was found in the name of a business is $E l$ Canelazo. 'Canelazo' is a hot drink consumed especially during traditional celebrations in the highlands of Ecuador (Figure 12). Some regionalisms from the coast of the country can also be illustrated by 'cangrejo del manglar' which means 'mangrove crab' and is a traditional dish from this region (Figure 13).

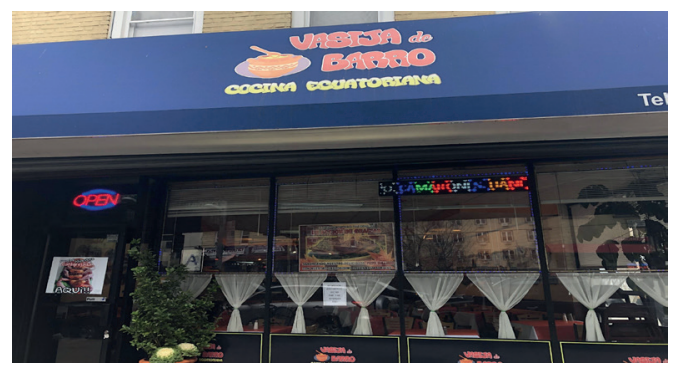

Figure 11. Vasija de Barro Restaurant

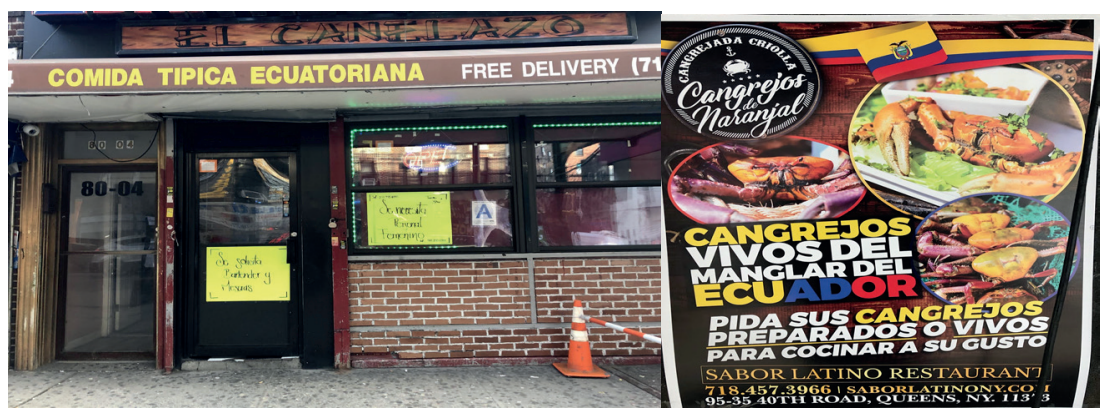

Figure 12. El Canelazo Restaurant

Figure 13. Ecuadorian Poster

Other semiotic symbols that are used by the Ecuadorian community might not be as obvious for people outside of this cultural group. For instance, in Figure 14 the sign reads 'Barcelona'. We might think that this sign refers to Barcelona in Spain or its soccer team. However, if we take a closer look, we can identify the coat of arms of Barcelona Sporting Club which is an Ecuadorian sports club from Guayaquil. Then, in the window display, we can observe some t-shirts from other Ecuadorian local teams such as Liga Deportiva Universitaria (LDU). The soccer shirts along with the name of the store conjunctly construct the meaning of this Ecuadorian store in a dynamic interaction of language and public display (Stroud \& Mpendukana, 2009). Nevertheless, we can also find merchandise from other worldwide teams. Therefore, as Bernardo-Hinesley and Gubitosi (s.f.) mentioned, the LL is not static or only relevant for one community, but it also accommodates the new space that is shared with other groups. 


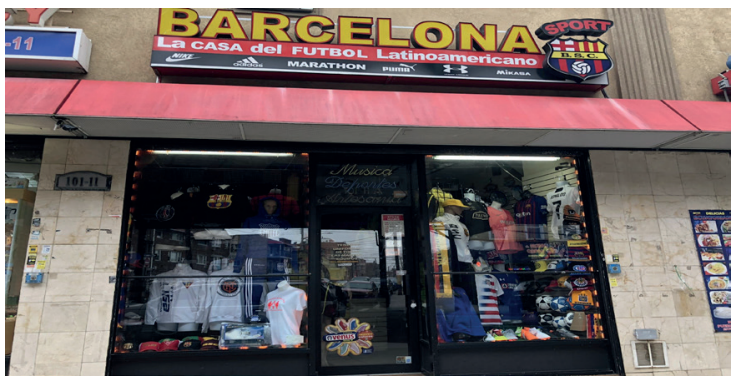

Figure 14. Sport Shop

The LL in these streets along Roosevelt Avenue is not only defined by the language use, but it also highlights specific characteristics from each community as we saw in the case of Ecuadorians. With these strategies, Ecuadorians have built and continue to build a new transnational identity using the LL as a resource to show ties with the motherland and the host country.

\section{Conclusions}

LL is an excellent tool for sociolinguists to understand how languages are used in the public space to build people's sense of place and identity. This identity construction is specifically important among people living in the diaspora since they have resettled in a different country, deterritorializing themselves from their homeland creating a new home away from home. This process is comprised of a reinterpretation and reconceptualization of the relationship between the native language of the new group and the languages spoken in the new country. In this reappropriation process various linguistic resources are used to show the translocality, moving across different paths of time and space (Blommaert, 2010; Johnstone, 2010; Moriarty, 2014).

Evidence of translocality and mobility are also shown among the Ecuadorian community living in Queens, as they have managed to replicate images of their homeland and created a sense of inclusiveness for both main groups of the Ecuadorian diaspora: people who have immigrated from the highlands, as well as from the coastal regions. As we have seen, Ecuadorian businesses and shops along Roosevelt Avenue in Queens utilize all the linguistic and semiotic resources that they have at their disposal to show their allegiances to Ecuador, while still making a new imagined community in a new, different nation. Ecuadorians have managed to reproduce the same businesses that they have had in their motherland, such as Austro Bank, but they have also recreated restaurants that sell typical food from different parts of their home country, as we discussed in the case of Ambato or Azogues above. Nevertheless, even though Ecuadorians are proud of showing 
they have come from diverse places and regions, Ecuadorians in Queens are prouder of all being Ecuadorians as they display their flag, colors and coat of arms. This ultimately confirms what Patiño-Santos (2015) pointed out, that the construction of identity in diasporic communities is frequently based on the homogenization of difference.

By recreating this ideal society where every Ecuadorian (from the coast or the highland area) is included, this diaspora group is inventing a new community and reinterpreting its own common ethnic characteristics. People in these conditions frequently invent traditions to reproduce and realize Anderson's imagined community (Hosbawn, 1983). Accordingly, diaspora groups use LL as a strategy not only to maintain their transnational identity, but also to build a unique distinctiveness in the recipient society (Woldemariam \& Lanza, 2015).

Regarding the differences Ecuadorians have with respect to other Latin American groups, our data shows that Ecuadorians distinguish themselves from other Latin America diaspora by their huge presence in the LL of Queens. In terms of quantitative results, Ecuadorians have presence in several kinds of shops beyond restaurants and are also dominant in the poster assemblages. We agree with Bernardo-Hinesley and Gubitosi (s.f.) that "linguistic landscape sheds light on the relationship between predominant and minority languages within a given context, it portrays the struggles between language groups over visibility in public spaces". As we compare monolingual and bilingual uses of Spanish among Ecuadorian diaspora and other groups, Ecuadorians show a greater index of loyalty to the Spanish language than any other Latin American group. Moreover, as Aronin and 0'Laoire (2013, p. 226) point out "(m)aterial culture modifies our existence to a considerable effect" and pervades the mode on how bilinguals relate with both their immediate and distant surroundings and other members of the community.

Furthermore, Ecuadorians not only differ on the amount of Spanish used in the LL signals of Ecuadorian origin and in the number of businesses and shops with Ecuadorian semiotic symbols, but also they differ in the quality and kind of the symbols: while Colombian and Mexican groups utilize hats, jeans, or chili peppers, Ecuadorians only use patriotic representations of their flag, colors and coat of arms.

Last but not least, Ecuadorians and other Latin American groups such as Mexicans and Colombians have made Roosevelt Avenue a de facto bilingual neighborhood. As we have seen, even businesses that are not of Latino origin use Spanish language signs in addition to English, the hegemonic language in the area, to attract the enormous quantity of Hispanics who frequent the street. We agree with Bernardo-Hinesley and Gubitosi (s.f.) that "the languages employed in signs in a specific area can provide a panorama that a 
spectator may visually discern meanwhile passing through its streets," and, concurrently, this scenery may reflect the linguistic situation of the city, region, or country. By modifying the LL of their surroundings, Ecuadorian diaspora has adapted the new place to make it more similar to what they have had in their old country reterritorializing the new space while constructing new identities.

\section{References}

Aronin, L. and Singleton, D. (2012). Multilingualism. <IMPACT on language and society 30>. Amsterdam/Philadelphia: John Benjamins. https://doi.org/10.1075/impact.30

Aronin, L. \& M. Ó Laoire. (2013). The material culture of multilingualism: moving beyond the linguistic landscape, International Journal of Multilingualism, 10(3), 225-235. https:// doi.org/10.1080/14790718.2012.679734

Backhaus, P. (2007). Linguistic Landscapes: A Comparative Study of Urban

Multilingualism in Tokyo. Clevedon: Multilingual Matters. https:/doi. org/10.21832/9781853599484

Ben-Rafael, E. (2009). A sociological approach to the study of linguistic landscapes. In E. Shohamy \& D. Gorter (Eds.), Linguistic landscape: Expanding the scenery (pp. 40-54). Abingdon: Routledge.

Ben-Rafael, E., Shohamy, E., Amara, M.H. and Trumper-Hecht, N. (2001) Linguistic landscape and multiculturalism: A Jewish-Arab comparative study. Unpublished research report.

Ben-Rafael, E., Shohamy, E., Amara, M., \& Trumper-Hecht, N. (2006). The symbolic construction of the public space: The case of Israel. International Journal of Multilingualism, 3(1), 7-31. https://doi.org/10.1080/14790710608668383

Ben-Rafael, E., Shohamy, E., \& Barni, M. Introduction: An approach to an 'ordered disorden'. In: E. Shohamy, E. Ben-Rafael \& M. Barni (eds.) Linguistic landscape in the city. Bristol: Multilingual Matters, p. xi-xxviii.

Bergad, L.W. (2016). The Latino Population of New York City 1990-2015. New York, NY: Center for Latin American, Caribbean, and Latino Studies at the CUNY Graduate Center.

Bernardo-Hinesley, S., Gubitosi, P. (Forthcoming). Linguistic landscape and the struggle for survival: The case of Cavite Chabacano. In: S. Hadi Mirvahedi (Ed.) Linguistic Landscape of Southeast Asia. Impact: Studies in Language, Culture and Society series. John Benjamins.

Blackwood, R., Lanza, E. \& Woldemariam, H. (2016). Negotiating and contesting identities in linguistic landscapes. London: Bloomsbury Publishing Plc. 
Blommaert, J. (2010). The sociolinguistics of globalization. Cambridge: Cambridge University Press. https://doi.org/10.1017/CB09780511845307

Blommaert, J. (2013). Ethnography, superdiversity and linguistic landscapes. Chronicles of complexities. Bristol: Multilingual Matters. https://doi.org/10.21832/9781783090419

Canagarajah, S. \& Silberstein, S. (2012) Diaspora Identities and Language. Journal of Language, Identity, and Education 11, pp. 81-84. https://doi.org/10.1080/15348458.2012.667296

Carson, L. \& King, L. (2016). Introduction. In: L. King \& L. Carson. (eds.) The multilingual city. Vitality, conflict and change. Bristol: Multilingual Matters.

Cenoz, J. (2013). Defining Multilingualism. Annual Review of Applied Linguistics 33, 3-18. https://doi.org/10.1017/S026719051300007X

Cenoz, J. \& Gorter, D. (2006) Linguistic landscape and minority languages. The International Journal of Multilingualism 3, 67-80. https://doi.org/10.1080/14790710608668386

Foner, N. (2007). How exceptional is New York? Migration and multiculturalism in the empire city. EthnicandRacialStudies.30(6),999-1023.https://doi.org/10.1080/01419870701599440

Gorter, D. (2018). Methods and Techniques for Linguistic Landscape Research: About Definitions, Core Issues and Technological Innovations. In Martin Pütz \& Neele Mundt (Hrsg.), Expanding the Linguistic Landscape: Multilingualism, Language Policy and the Use of Space as a Semiotic Resource, 38-57. Bristol: Multilingual Matters. https:// doi.org/10.21832/9781788922166-005

Gorter, D. \& J. Cenoz. (2015). Translanguaging and linguistic landscapes. Linguistic Landscape 1, 54-74. https://doi.org/10.1075/11.1.1-2.04gor

Gratton, B. (2005) Ecuador en la historia de la migración internacional: ¿modelo o aberración? In Herrera, G., Carrillo, M.C. and Torres, A. (Eds) La Migración Ecuatoriana: transnacionalismo, redes e identidades. Quito: Facultad Latinoamericana de Ciencias Sociales Sede Ecuador, 32-55.

Gratton, B. (2007). Ecuadorians in the United States and Spain: History, gender and niche formation. Journal of Ethnic and Migration Studies, 33 (4): 581-599. https://doi. org/10.1080/13691830701265446

Gubitosi, P. (2019). La expresión de la pasividad en los hablantes de español en Houston, Texas. In: M. Haboud (ed.) Lenguas en contacto: desafíos en la diversidad. Quito: Centro de publicaciones PUCE; pp. 135-161.

Herrera, G. (2005). Mujeres ecuatorianas en las cadenas globales del cuidado, in Herrera, G., Carrillo, M.C. and Torres, A. (Eds) La Migración Ecuatoriana: transnacionalismo, redes e identidades. Quito: Facultad Latinoamericana de Ciencias Sociales Sede Ecuador, 281303. 
Hosbawn, E. (1983). Introduction: Inventing traditions. In: E. Hosbawn \& T. Ranger (eds.). The invention of traditions. Cambridge: Cambridge University Press, 1-14. https://doi. org/10.1017/CB09781107295636.001

Huebner,T. (2006). Bangkok'slinguisticlandscapes: Environmental print codemixing, and language change. In D. Gorter (ed) Linguistic Landscape: A New Approach to Multilingualism (pp. 31-51). Clevedon: Multilingual Matters. https://doi.org/10.21832/9781853599170003

Johnstone, B. (2010). Indexing the local. In Coupland, N. (Ed.), The bandbook of language and globalization (pp. 386-405). Oxford, UK: Blackwell. https:/doi. org/10.1002/9781444324068.ch17

Landry, R \& Bourhis, R. (1997). Linguistic Landscape and ethnolinguistic vitality: An empirical study. Journal of Language and Social Psychology 16(1), 23-49. https://doi. org/10.1177/0261927X970161002

Laughlin, J. M. (2001). Reimaging the nation-state. The contested terrain of nation-building. Pluto Books.

Lipski, M. (2003). Contacto y conflicto: el vocalismo del castellano andino (Imbabura, Ecuador). Universidad del Estado de Pennsylvania. Estados Unidos.

Lytra, V. (2012). Multilingualism and multimodality. In M. Martin-Jones, A. Blackledge and A. Creese (eds.), The Routledge Handbook of Multilingualism. Milton: Routledge, pp. 521537.

Machin, D. (2007). Introduction to multimodal analysis. London: Hodder Education.

Malinowski, D. (2009). Authorship in the linguistic landscape. A multimodal performative view. In: E. Shohamy and D. Gorter (eds). Linguistic Landscapes: Expanding the scenary. London: Routledge, pp. 302-312.

Moriarty, M. (2014). Languages in motion: Multilingualism and mobility in the linguistic landscape. International Journal of Bilingualism, 18(5), 457-463. https://doi. org/10.1177/1367006913484208

Nayak, A. (2010). Race, affect, and emotion: young people, racism, and graffiti in the postcolonial English suburbs. Environment and Planning, 42, pp. 2370-2392. https://doi. org/10.1068/a42177

Patiño-Santos, A. (2015). On being Colombian in La Sagrada Familia Neighborhood. In: R. Márquez Reiter \& L. Martín Rojo (eds.). A sociolinguistics of Diaspora. Latino Practices, Identities and Ideologies. Routledge: New York, 102-121. 
Pennycook, A. (2019). Linguistic landscapes and semiotic assemblages. In: M. Pütz \& N. Mundt (eds.). Expanding the linguistic landscape. Linguistic diversity, multimodality and the use of space as a semiotic resource. Bristol: Multilingual Matters, pp. 75-88. https://doi. org/10.21832/9781788922166-007

Pütz, M. \& Mundt, N. (2019). Multilingualism, multimodality and methodology: Linguistic landscape research in the context of assemblages, ideologies and (in)visibilities. An introduction. In: M. Pütz \& N. Mundt (eds.). Expanding the linguistic landscape. Linguistic diversity, multimodality and the use of space as a semiotic resource. Bristol: Multilingual Matters, pp 1-22. https://doi.org/10.21832/9781788922166-003

Rosa, J. (2015). Nuevo Chicago? Language, Diaspora, and Latina/o Panethic Formations. In: Márquez Reiter, R. and L. Martín Rojo (eds.): A sociolinguistics of Diaspora. Latino Practices, Identities and Ideologies. Routledge: New York, pp. 31-47.

Salzmann, T. Language, identity and urban space. The language use of Latin American migrants. Frankfurt: Peter Lang.

Shohami, Elana. (2015). LL research as expanding language and language policy. Linguistic Landscape 1:1/2, 152-171. https://doi.org/10.1075/11.1.1-2.09sho

Stroud, C. (2016). Turbulent linguistic landscape and the semiotics of citizenship. In R. Blackwood, E. Lanza \& H. Woldemariam. (eds.). Negotiating and contesting identities in linguistic landscapes. London: Bloomsbury Publishing Plc.

Stroud, C. \& Mpendukana, S. (2009). Towards a material ethnography of linguistic landscape: Multilingualism, mobility and space in a South African township.Journal of Sociolinguistics 13(3), 363-386. https://doi.org/10.1111/j.1467-9841.2009.00410.x

Vandenbroucke, M. (2015) Language visibility, functionality and meaning across

various TimeSpace scales in Brussels' multilingual landscapes. Journal of Multilingual and Multicultural Development 36(2), 163-181.

Vertovec, S. (2007). Super-diversity and its implications. Ethnic and Racial Studies 30 (๑), 10241054. https://doi.org/10.1080/01419870701599465

Woldemariam, H. and E. Lanza. (2015) Imagined community. The linguistic landscape in a diaspora. Linguistic Landscape 1:1/2, 172-190. https://doi.org/10.1075/11.1.1-2.10wol 